\title{
PENERAPAN MODEL COOPERATIVE LEARNING TERHADAP PEMBELAJARAN PENDIDIKAN AGAMA ISLAM DALAM PEMBENTUKAN PERILAKU BELAJAR SISWA MADRASAH TSANAWIYAH AL IKHLAS MOWEWE
}

\author{
Muhammad Nur \\ Madrasah Tsanawiyah Al Ikhlas Mowewe \\ Email: muhnoer1971@gmail.com
}

\begin{abstract}
Abstrak
Penelitian ini mengkaji tentang penerapan model Cooperative Learning $(C L)$ terhadap pembelajaran Pendidikan Agama Islam (PAI) dalam pembentukan perilaku belajar siswa Madrasah Tsanawiyah (MTs) Al Ikhlas Mowewe. Penelitian ini bertujuan untuk menganalisis proses pada penerapan model Cooperative Learning $(C L)$ terhadap pembelajaran Pendidikan Agama Islam (PAI) dalam pembentukan perilaku belajar siswa Madrasah Tsanawiyah (MTs) Al Ikhlas Mowewe. Jenis penelitian ini adalah penelitian kualitatif berbentuk studi kasus menggunakan analisis deskriptif. Sumber data primer yaitu data utama yang bersumber dari Kepala Madrasah, guru dan siswa. Sedangkan sumber data sekunder yaitu data pendukung tentang kondisi objektif Madrasah Tsanawiyah (MTs) Al Ikhlas Mowewe yang dirinci, diolah, dan dianalisis. Teknik dan prosedur pengumpulan data yang meliputi observasi, wawancara, dan dokumentasi. Teknik analisis data dan pengolahan data dilakukan melalui proses reduksi, penyajian, dan kesimpulan data. Pengujian keabsahan data meliputi uji kredibilitas dan uji konfirmabilitas. Hasil penelitian menunjukkan bahwa Penerapan model Cooperative Learning $(C L)$ terhadap pembelajaran Pendidikan Agama Islam (PAI) dalam pembentukan perilaku belajar siswa yang diwujudkan dalam bentuk-bentuk perilaku belajar siswa yang meliputi: kebiasaan, keterampilan, pengamatan, berpikir assosiatif dan daya ingat, sikap, Inhibisi, apresiasi, berpikir rasional dan kritis dan tingkah laku afektif yang pelaksanaannya melalui penerapan tiga tipe, yakni : tipe belajar kelompok (learning together), tipe diskusi kelompok (group discussion), dan tipe Jigsaw Implikasi hasil karya ilmiah ini diharapkan dapat memberi informasi terhadap dunia pendidikan. Penerapan model Cooperative Learning $(C L)$ terhadap pembelajaran Pendidikan Agama Islam (PAI) dalam pembentukan perilaku belajar siswa diharapkan mampu melahirkan kebijaksanaan dan kearifan dalam menyikapi kompleksitas permasalahan dalam pelaksanaan pembelajaran Pendidikan Agama Islam (PAI) sehingga kedepan akan menghasilkan dan mampu menemukan solusi-solusi yang makin cerdas dan aplikatif.
\end{abstract}

Kata Kunci : Cooperative Learning, Pembelajaran, Perilaku Belajar 


\begin{abstract}
The object of this thesis is to research the application of cooperative learning model on learning of Islamic education in establishing students learning behaviour at AlIkhlash Islamic Junior High School of Mowewe. The purpose of this study is to analyze the application of Cooperative Leaning Model in establishing student learning behaviour.The research used qualitative approach, and case study method with descriptive analysis.Primary data sourcedfrom Head of Madrasah, teachers and students. While the secondary data sourced from data about the objective condition of Al-Ikhlas Islamic Junior High School of Mowewe which is detailed, processed, and analyzed. The research technique included observation, interviews, and documentation. Data is processed and analyzed through reduction, presentation, and data conclusions. Validity test data include credibility and confirmbility test.The results of this study are The application of Cooperative Learning on the Islamic education learning in student learning behaviour is done through planning. Various forms of students learning, behaviour consist of habit, skill, observation, associative thinking, rememberance, attitude, inhibition, appreciation, rational and critical thinking, as well as affective behaviour. Is done through three types: learning together, group discussion, and Jigsaw.The implication of this study is expected to inform and contribute in educational improvement. It hoped from the application of Cooperative Learning in Islamic education learning in student learning behaviour to createthe policies and wisdom to deal the complexity of learning problems.
\end{abstract}

Keywords: Cooperative Learning, Establising Students, Learning Behaviour

\title{
Pendahuluan
}

Salah satu tujuan dari proses pembelajaran yang diharapkan saat ini adalah untuk meningkatkan pengetahuan, pengalaman dan keterampilan siswa yang ditunjukkan melalui bentuk perilaku belajar siswa yang baik dan positif. Untuk membentuk perilaku belajar siswa yang diinginkan tersebut, dapat dipengaruhi oleh berbagai faktor, diantaranya: guru, siswa dan model pembelajaran. Untuk mewujudkan tujuan tersebut, guru sebagai fasilitator sebaiknya dapat berperan aktif dan mampu memberikan pelayanan kepada siswa sesuai dengan karakter mereka masing-masing. Guru dituntut dapat membuat suasana pembelajaran yang dinamis, aktif, kreatif, nyaman dan menyenangkan.

Pembelajaran yang dilaksanakan menghendaki agar peserta didik atau siswa dapat aktif dalam proses pembelajaran untuk mengembangkan potensi yang ada pada dirinya. Kondisi ini tidak dapat diwujudkan apabila dalam pembelajaran yang berlangsung di sekolah dan madrasah masih menggunakan pendekatan lama, yakni 
pendekatan pembelajaran konvensional (teacher centered). Untuk mencapai tujuan tersebut, paradigma pembelajaran harus diubah dari paradigma mengajar ke paradigma belajar. Peranan guru dalam pembelajaran mesti dirubah dari pengajar menjadi fasilitator, motivator, konselor, pembimbing, mediator, dan evaluator.

Untuk mencapai kualitas pembelajaran yang diinginkan, maka penggunaan model pembelajaran menentukan keberhasilan pembelajaran termasuk untuk pengembangannya. Penerapan model pembelajaran merupakan rangkaian prosedur yang sistematis terhadap pelaksanaan pembelajaran. Salah satu model pembelajaran yang dapat dijadikan upaya dalam pembentukan perilaku belajar siswa adalah melalui penerapan model Cooperative Learning $(C L)$. Pembelajaran model Cooperative Learning $(C L)$ sebagai bentuk strategi dalam mengajar yang digunakan oleh guru agar siswa saling membantu dalam mempelajari suatu bahan ajar atau materi. Oleh karena itu, belajar menggunakan model Cooperative Learning $(C L)$ ini juga dinamakan belajar teman sebaya. Model Cooperative Learning $(C L)$ dikembangkan untuk mencapai tiga tujuan penting pembelajaran, yaitu pembentukan perilaku belajar akademik, penerimaan terhadap keragaman, dan pengembangan keterampilan sosial. Bahwa model Cooperative Learning $(C L)$ dapat digunakan untuk mengajarkan materi yang sifatnya kompleks, membantu mencapai tujuan pembelajaran yang berdimensi sosial, dan hubungan antara manusia.

Perilaku belajar siswa dalam penerapan model Cooperative Learning (CL) merupakan suatu sikap yang muncul dari dalam diri siswa dalam menanggapi dan merespon setiap kegiatan pembelajaran yang terjadi, menunjukkan sikap kerjasama, bersemangat, berempati, peduli, dan bertanggungjawab atas kesempatan belajar yang diberikan padanya. Wujud perilaku belajar yang baik bagi siswa berhubungan pula dengan beberapa hal, yaitu: perilaku belajar dalam membaca buku, mengunjungi perpustakaan, menghargai perbedaan, sopan santun, mengulangi pelajaran dan perilaku baik lainnya yang didasari semangat kebersamaan saat pembelajaran berlangsung maupun setelah pembelajaran. Penerapan model Cooperative Learning $(C L)$ terhadap pembelajaran Pendidikan Agama Islam (PAI) dalam pembentukan perilaku belajar siswa Madrasah Tsanawiyah (MTs) Al Ikhlas Mowewe dilaksanakan melalui tipe kerja kelompok (learning together), diskusi kelompok (group discussion), dan Jigsaw dalam pembelajaran namun hasilnya belum maksimal dengan beberapa indikator, seperti: beberapa siswa masih kurang menunjukkan keseriusan belajar, kerja sama, kedisiplinan, 
apresiasi dan keterampilan masih kurang terbangun dengan baik sebagai bentuk perilaku belajar siswa yang diharapkan dalam pembelajaran melalui penerapan model Cooperative Learning $(C L)^{1}$

Penerapan model Cooperative Learning $(C L)$ terhadap pembelajaran Pendidikan Agama Islam (PAI) dalam pembentukan perilaku belajar siswa Madrasah Tsanawiyah (MTs) Al Ikhlas Mowewe menggunakan tiga tipe yakni: learning together, group discussion dan Jigsaw dengan mengikuti langkah-langkah pembelajaran model Cooperative Learning $(C L)$. Melalui penerapan model Cooperative Learning $(C L)$ menekankan pada pemberian kesempatan belajar yang lebih luas dalam suasana yang kondusif yang dirasakan oleh siswa untuk memperoleh dan mengembangkan pengetahuan, sikap dan perilaku belajar yang kelak dapat dirasakan ditengah masyarakat. ${ }^{2}$

Pelaksanaan pembelajaran di Madrasah Tsanawiyah Al Ikhlas Mowewe, menuntut guru-guru PAI lebih aktif, kreatif dan inovatif sehingga pembelajaran dapat memberi nilai dan manfaat dalam pembentukan perilaku belajar siswa. Diantara model yang dianggap efektif dan efisien dilakukan dalam pembelajaran adalah penerapan model Cooperative Learning $(C L)$ yang pelaksanaannya disesuaikan dengan kondisi siswa, Madrasah, sarana dan lingkungan yang sesuai dengan materi yang diajarkan oleh setiap guru mata pelajaran Pendidikan Agama Islam (PAI). Bahwa model Cooperative Learning (CL) merupakan model pembelajaran yang dilaksanakan secara berkelompok, mengkonstruksi konsep, menemukan persoalan-persoalan baru atau menyelesaikan persoalan. Guru bertugas mengontrol, memfasilitasi dan meminta tanggungjawab dari masing-masing kelompok berupa laporan atau dalam bentuk presentasi. Sintak penerapan model Cooperative Learning $(C L)$ adalah: informasi, kerja kelompok, presentasi hasil kelompok dan pelaporan.

Bagaimana Penerapan model Cooperative Learning $(C L)$ terhadap pembelajaran Pendidikan Agama Islam (PAI) dalam pembentukan perilaku belajar siswa Madrasah Tsanawiyah (MTs) Al Ikhlas Mowewe? Temuan sementara menunjukkan bahwa penerapan model Cooperative Learning $(C L)$ terhadap pembelajaran Pendidikan Agama Islam (PAI) dalam pembentukan perilaku belajar siswa menggunakan tiga tipe model Cooperative Learning $(C L)$ belum optimal pada pembelajaran, seperti: beberapa siswa kurang bersemangat yang ditunjukkan pada ketidakseriusan, kurang terampil menyusun

\footnotetext{
${ }^{1}$ Observasi pada tanggal 5 Maret 2018.

${ }^{2}$ Dokumen Sekolah, pada tanggal 9 April 2018.
} 
struktur kelompok, kurang berpikir rasional, kreatif dan kritis dalam diskusi kelompok, kerjasama kelompok kurang terbangun, kurang aktifnya beberapa siswa dalam kelompok, kemampuan berpikir asosiatif dan daya ingat beberapa siswa terkesan lemah dan perilaku afektif beberapa siswa dengan membeda-bedakan teman dalam bergaul di lingkungan sekolah. ${ }^{3}$ Dugaan sementara, belum optimalnya penerapan model Cooperative Learning $(C L)$ karena baru beberapa kali dilaksanakan, guru yang menerapkan belum maksimal memahami langkah-langkah pembelajaran model Cooperative Learning $(C L)$ oleh karena terbatasnya waktu dan sarana pembelajaran yang tersedia. Penerapan model Cooperative Learning $(C L)$ dalam pembelajaran pelaksanaannya diharapkan terjalin kerjasama dan interaksi siswa dalam kelompok.

Penelitian sebelumnya ditemukan bahwa penerapan model Cooperative Learning (CL) terhadap pembelajaran PAI (Fiqh) di MTs. Sunan Giri Prigen Gutter Pasuruan, dalam penelitian tersebut menyatakan: Bahwa penerapan pembelajaran PAI (Fiqh) menggunakan model Cooperative Learning $(C L)$ pada tipe Jigsaw yang dilaksanakan dalam ruangan kelas membuat siswa aktif, kreatif dan menyenangkan. Dalam pembelajaran model Cooperative Learning $(C L)$ tipe Jigsaw, guru yang tidak familiar dalam menggunakan media tetap dapat melaksanakan tugas pembelajaran dengan baik dan berhasil sesuai dengan rencana pembelajaran. ${ }^{4}$ Penelitian ini kurang memberikan penjelasan bentuk-bentuk perilaku belajar siswa yang lain dalam ruangan kelas sehubungan dengan penerapan model Cooperative Learning (CL) tipe Jigsaw seperti: kebiasaan, keterampilan, berpikir kritis, berpikir asosiatif dan daya ingat, disiplin, apresiasi, Inhibisi, dan perilaku afektif serta hambatan-hambatan lain yang ditemui guru selain dari penggunaan media pembelajaran yang menurut penelitian ini tidak menjadi halangan dalam penerapan model Cooperative Learning $(C L)$.

Kajian ini fokus terhadap penerapan model Coopearative Learning $(C L)$ terhadap pembelajaran Pendidikan Agama Islam (PAI) dalam pembentukan perilaku belajar siswa sebagai objek penelitian, dengan pertimbangan bahwa penerapan model Cooperative Learning $(C L)$ terhadap pembelajaran Pendidikan Agama Islam (PAI) di Madrasah Tsanawiyah (MTs) Al Ikhlas Mowewe adalah hal yang tepat. Temuan awal menunjukkan bahwa Penerapan model Cooperative Learning $(C L)$ terhadap pembelajaran Pendidikan

\footnotetext{
${ }^{3}$ Observasi pada tanggal 2 Maret 2018.

${ }^{4}$ Hikmah Badiatul, 2017, Pembelajaran Kooperatif (Studi dalam pembelajaran Fiqh tipe Jigsaw MTs Sunan Giri Prigen Gutter Pasuruan) Journal Islamic Education, (online)Vol.2, no.1 Http://ejournal.Stitmuhbangil.ac.id/index.php/Jie/View/44, diakses, pada tanggal 11 Mei 2018.
} 
Agama Islam (PAI) dalam pembentukan perilaku belajar siswa belum optimal pelaksanaannya dalam membentuk perilaku belajar siswa yang diinginkan dalam pembelajaran model Cooperative Learning $(C L)$. Realitas ini memotivasi untuk melakukan penelitian dan pengkajian lebih lanjut guna menemukan fakta yang sebenarnya terjadi di lapangan.

\section{Metode Penelitian}

Penelitian ini dilaksanakan di Madrasah Tsanawiyah Al Ikhlas Mowewe Kecamatan Mowewe Kabupaten Kolaka Timur. Masa penelitian ini berlangsung selama tiga bulan, yaitu dimulai pada bulan Februari hingga April 2018. Teknik pengumpulan data dilakukan melalui teknik observasi, wawancara dan dokumentasi. Pedoman observasi disusun berdasarkan kebutuhan data, demikian pula dengan teknik wawancara, dokumentasi yang berisi obyek dan uraian sesuai tujuan penelitian. Perpanjangan waktu adalah pilihan dalam menyelesaikan pengumpulan data sehingga benar-benar akurat dan dapat dipertanggungjawabkan. Penelitian ini menggunakan pendekatan kualitatif deskriptif yang bertujuan mengumpulkan data-data, fakta, berupa tulisan dan perilaku yang dapat diamati pada subjek penelitian. Sedangkan jenis penelitian yang digunakan adalah penelitian kualitatif berbentuk studi kasus yaitu pengujian secara rinci terhadap suatu latar, suatu subjek, atau suatu peristiwa. Dalam penelitian berbentuk studi kasus ini menitik beratkan pada penerapan model Cooperative Learning $(C L)$ terhadap pembelajaran Pendidikan Agama Islam (PAI) dalam pembentukan perilaku belajar siswa Madrasah Tsanawiyah (MTs) Al Ikhlas Mowewe.

\section{Pengertian Cooperative Learning (CL)}

Istilah Cooperative Learning $(C L)$ atau pembelajaran gotong royong. Cooperative Learning dalam penelitian ini disingkat dengan $C L$ terdiri dari dua kata yaitu Cooperative dan Learning. Cooperative atau kerjasama ialah cara individu mengadakan relasi dan bekerjasama dengan individu lain untuk mencapai tujuan bersama. Sedangkan Learning adalah suatu proses melalui pengalaman yang menyebabkan perubahan permanen dalam pengetahuan dan perilaku. Learning juga dapat diartikan sebagai kegiatan memperoleh pengetahuan, perilaku dan keterampilan dengan cara mengelola bahan ajar atau materi. 
Menurut Slavin, model Cooperative Learning (CL), merupakan model pembelajaran dimana siswa bekerja dalam kelompok yang memiliki kemampuan heterogen ${ }^{5}$. Model Cooperative Learning (CL) mengacu pada model pembelajaran dimana siswa bekerja bersama dalam kelompok kecil saling membantu dalam belajar. Model Cooperative Learning $(C L)$ sebagai bentuk pembelajaran dengan cara siswa belajar dan bekerja dalam kelompok kecil secara kolaboratif yang terdiri dari empat sampai enam orang dengan struktur kelompok dan keanggotaannya bersifat heterogen. ${ }^{6}$ Setiap anggota kelompok bukan hanya belajar materi yang diajarkan, akan tetapi juga membantu anggota lain untuk belajar. Model Cooperative Learning (CL) menganut prinsip saling ketergantungan positif (Posititive Interdependence), tanggungjawab perseorangan (Individual Accaontability), tatap muka (Face to face Interaction), keterampilan sosial (Social Skill) dan proses kelompok (Group Processing).

Pembelajaran model Cooperative Learning $(C L)$, dimana siswa dilatih untuk bekerja sama dengan temannya secara sinergis, integral dan kombinatif. Selain itu, siswa juga diajak untuk menghindari sifat egois, individualis, serta kompetisi yang tidak sehat sedini mungkin agar masing-masing siswa tidak memetingkan kepentingan pribadi atau kelompoknya Pembelajaran model Cooperative Learning $(C L)$ terhadap pembelajaran Pendidikan Agama Islam (PAI) yang dilaksanakan saat ini menggunakan beberapa model atau tipe yang disesuaikan dengan materi yang akan diberikan, maka guru-guru Pendidikan Agama Islam (PAI) perlu melihat salah satu tujuan proses pembelajaran yakni meningkatkan pengetahuan, pengalaman dan keterampilan siswa yang ditunjukkan melalui bentuk perilaku belajar siswa yang baik dan positif. Untuk membentuk perilaku belajar siswa yang diinginkan perlu memperhatikan beberapa faktor yang mempengaruhi, antara lain: guru, siswa dan model pembelajaran.

\section{Karakteristik model Cooperative Learning (CL)}

Pembelajaran model Cooperative Learning $(C L)$ berbeda dengan strategi pembelajaran yang lain. Perbedaan tersebut dapat dilihat dari proses yang menekankan pada proses kerja sama dalam kelompok. Tujuan yang ingin dicapai pada pembelajaran

${ }^{5}$ Slavin R.E, Research on Cooperative Learning and: What We Know, What We Need to Know, Contemporary Educational Psychology (terjemah Nurlita Yusron) (Bandung: Nusa Media Bandung, 2008), h. 39.

${ }^{6}$ Rusman, “ Model- Model Pembelajaran, Mengembangkan Profesionalisme Guru”, (Jakarta: Rajawali Press, 2011), h. 202. 
model Cooperative Learning $(C L)$ tidak hanya pada penguasaan materi pembelajaran (Akademik), akan tetapi dilihat pada prosesnya, apakah terdapat unsur kerja sama kelompok pada materi pembelajaran, adanya pembelajaran tim atau kerjasama kelompok, kemauan untuk bekerja sama dan keterampilan bekerja sama. Hal inilah menjadi karakteristik dari pembelajaran model Cooperative Learning $(C L)$. Keberhasilan pembelajaran model Cooperative Learning $(C L)$ ditentukan oleh keberhasilan secara kelompok. Setiap anggota kelompok bukan saja diatur tugas dan tanggungjawab masingmasing, akan tetapi ditanamkan perlunya saling membantu dalam kelompok. ${ }^{7}$ Pembelajaran model Cooperative Learning $(C L)$ memiliki empat fungsi pokok, yaitu: perencanaan, pelaksanaan, organisasi dan kontrol (evaluasi). Fungsi- fungsi tersebut dilakukan untuk pencapaian tujuan pembelajaran secara efektif dan efisien.

\section{Kelebihan dan Kelemahan model Cooperative Learning (CL)}

Kelebihan model Cooperative Learning $(C L)$ diantaranya:

1. Model Cooperative Learning (CL) siswa tidak menggantungkan pada guru, akan tetapi dapat menumbuhkan kepercayaan, kemampuan berpikir, menemukan informasi dari berbagai sumber dan belajar dari siswa lain.

2. Model Cooperative Learning ( $C L)$ dapat membantu siswa untuk respek pada orang lain dan menyadari akan segala keterbatasannya serta mampu menerima perbedaan.

3. Model Cooperative Learning $(C L)$ dapat membantu memberdayakan setiap siswa untuk bertanggungjawab dalam belajar.

4. Model Cooperative Learning $(C L)$ dapat meningkatkan prestasi akademik, kemampuan sosial, mengembangkan rasa percaya diri, hubungan interpersonal, keterampilan mengatur waktu dan sikap positif terhadap sekolah.

5. Model Cooperative Learning $(C L)$ dapat membantu memberdayakan setiap siswa untuk lebih bertanggungjawab dalam belajar.

6. Model Cooperative Learning $(C L)$ dapat mengembangkan kemampuan siswa dalam menguji ide dan pehamannya sendiri, serta menerima umpan balik. Siswa dapat memecahkan masalah karena keputusan yang dibuat adalah tanggungjawab bersama kelompok.

7. Model Cooperative Learning (CL) dapat meningkatkan kemampuan siswa dalam menggunakan informasi dan kemampuan belajar abstrak menjadi nyata (riil).

8. Model Cooperative Learning $(C L)$ dalam penerapannya dimana interaksi yang terjadi dengan munculnya kecenderungan baru dan telah berubah serta memberikan rangsangan pada situasi yang dihadapi siswa untuk berpikir dan bersikap. ${ }^{8}$

\footnotetext{
${ }^{7}$ Wina Sanjaya, Strategi Pembelajaran Berorientasi Standar Proses, (Jakarta: Kencana Predana Media Group,2012), h. 246.

${ }^{8}$ Fishman, 2017.com, makalah-psikologi-belajar-manifestasi-perilaku belajar.php, (online),http://www.Kosmaext, 2017.com. di akses 11 Mei 2018.
} 
Kelemahan model Cooperative Learning $(C L)$ diantaranya: Bagi siswa yang dianggap memiliki kelebihan, merasa terhambat oleh siswa yang kurang memiliki kemampuan. Akibatnya, dapat mengganggu iklim kerja sama kelompok:

1. Sesuai dengan ciri utama dari model Cooperative Learning $(C L)$ dimana siswa saling membelajarkan. Karena itu, jika tanpa adanya peer teaching yang efektif, dibanding pengajaran langsung dari guru, bisa terjadi cara belajar apa yang seharusnya dipelajari tidak pernah dicapai oleh siswa.

2. Penilaian yang diberikan dalam model Cooperative Learning $(C L)$ didasarkan pada hasil kerja kelompok. Namun demikian, guru perlu menyadari, bahwa perilaku belajar yang diharapkan adalah perilaku belajar setiap siswa.

3. Keberhasilan model Cooperative Learning (CL) dalam mengembangkan kesadaran dalam kelompok memerlukan waktu yang cukup panjang, oleh sebab itu perlu diterapkan berulang kali.

4. Meskipun kemampun bekerjasama merupakan kemampuan yang sangat penting bagi siswa, akan tetapi banyak aktivitas dalam kehidupan yang hanya didasarkan pada kemampuan individual. Idealnya melalui model Cooperative Learning $(C L)$ selain siswa belajar bekerja sama, siswa juga harus belajar membangun kepercayaan diri. ${ }^{9}$

Bahwa meskipun kemampuan bekerjasama merupakan kemampuan yang sangat penting bagi siswa, akan tetapi banyak pula aktivitas dalam kehidupan yang hanya didasarkan pada kemampuan individual. Idealnya melalui penerapan model Cooperative Learning $(C L)$ selain siswa belajar bekerja sama juga harus membangun kepercayaan diri.

\section{Bentuk model Cooperative Learning (CL)}

Diantara bentuk model, tipe Cooperative Learning $(C L)$ adalah:

\section{Learning Together (Belajar Kelompok)}

Belajar kelompok atau biasa juga disebut belajar (learning together) merupakan kumpulan beberapa orang dengan variasi kemampuan yang berbeda (abilities group) yang saling belajar, saling berbagi pendapat dan saling membantu dengan kewajiban setiap anggota harus benar-benar memahami jawaban atau penyelesaian tugas yang diberikan kepada kelompok tersebut. Pada tipe ini pertanyaan atau permintaan bantuan kepada guru dilakukan hanya jika mereka sudah benar-benar kehabisan akal. Terpenting pada model Cooperative Learning $(C L)$ ini adalah adanya saling ketergantungan dalam arti positif, adanya interaksi tatap muka diantara anggota, keterlibatan anggota sangatlah diperhitungkan dan selain itu menggunakan keterampilan pribadi untuk mengembangkan keterampilan kelompok.

\footnotetext{
${ }^{9}$ Supriyono, Psikologi Belajar, (Jakarta: PT.Rineka Cipta, 2011), h. 102.
} 


\section{Group Discussion (Diskusi Kelompok)}

Merupakan satu tipe dari model Cooperative Learning $(C L)$ yang tertua dan sering digunakan. Diskusi merupakan kegiatan kelompok untuk memecahkan suatu masalah dengan tujuan mendapatkan pengertian bersama yang lebih jelas dan lebih teliti tentang sesuatu, atau untuk merampungkan keputusan bersama. Model atau tipe ini dilakukan dalam mempelajari bahan ajar atau materi dengan jalan kerja sama atau musyawarah.

3. Jigsaw

Model Jigsaw dikembangkan oleh Elliot Aranson, kemudian diadaptasi oleh Slavin. Teknik ini serupa dengan pertukaran kelompok, bedanya setiap siswa mengajarkan sesuatu. Hal ini merupakan alternatif yang cukup menarik jika terdapat materi yang dapat disegmentasikan. Setiap siswa mempelajari setiap bagian yang bila digabungkan akan membentuk pengetahuan yang terpadu. Pembelajaran model Cooperative Learning $(C L)$ tipe Jigsaw cocok diterapkan pada semua tingkatan kelas. Pada teknik ini, guru memperhatikan latar belakang pengalaman siswa dan membantu siswa mengaktifkannya agar bahan pelajaran menjadi bermakna dan siswa mempunyai banyak kesempatan untuk mengolah informasi dan meningkatkan keterampilan. ${ }^{10}$

Pada prinsipnya model atau tipe dalam penerapan model Cooperative Learning $(C L)$ tidak terbatas pada beberapa tipe saja, akan tetapi cukup beragam. Penggunaan model, tipe dalam pelaksanaan pembelajaran tergantung pada guru yang bersangkutan tipe mana yang dianggap mudah, cocok dan tepat disesuaikan dengan materi atau bahan ajar yang akan dilaksanakan.

\section{Langkah-Langkah pembelajaran model Cooperative Learning (CL)}

Beberapa langkah-langkah utama dalam pembelajaran model Cooperative Learning ( $C L)$, yaitu: 1. Menyampaikan tujuan dan memotivasi: Guru menyampaikan tujuan pembelajaran dan memberikan motivasi, 2. Menyajikan informasi: Guru menyajikan informasi kepada siswa dengan jalan demonstrasi melalui bacaan kepada siswa, 3. Mengorganisasikan siswa dalam kelompok kerja sama: Guru menjelaskan kepada siswa tentang bagaimana siswa membentuk kelompok belajar dan memberi

\footnotetext{
${ }^{10}$ Melvin L. Silbermen,” Active Learning” 101 Strategi Pembelajaran Aktif, (Jogjakarta: Pustaka Insan Madani,2007), h. 168.
} 
bantuan kepada setiap kelompok agar melakukan kerja sama yang efektif, 4. Membimbing kelompok kerja dan belajar: Guru membimbing setiap kelompok dalam kerja sama kelompok, 5. Evaluasi: Guru mengevaluasi hasil pembelajaran kelompok atau setiap kelompok mempresentasikan hasil kerja kelompoknya, 6. Memberikan penghargaan: Guru mencari cara menghargai atau mengapresiasi hasil kerja kelompok baik secara individu maupun kelompok. ${ }^{11}$

Mengetahui dan memahami langkah-langkah pembelajaran model Cooperative Learning $(C L)$ memudahkan penerapan model Cooperative Learning $(C L)$ sehingga diharapkan dapat merangsang dan menggugah potensi siswa secara optimal dalam suasana belajar pada kelompok-kelompok kecil dari beberapa orang siswa. Melalui penerapan model Cooperative Learning $(C L)$ akan berkembang suasana belajar yang terbuka dalam dimensi kesejawatan. Inti model Cooperative Learning $(C L)$ adalah konsep synergy, yakni energi atau tenaga yang terhimpun melalui kerjasama sebagai salah satu fenomena kehidupan masyarakat ${ }^{12}$. Alasan penting mengapa penerapan model Cooperative Learning $(C L)$ perlu diterapkan di sekolah dan madrasah, karena sejalan dengan proses yang terjadi diera globalisasi terjadi pula transformasi sosial, ekonomi dan demografis yang menghendaki sekolah dan madrasah menyiapkan peserta didik atau siswa dengan keterampilan hidup bermasyarakat sehingga mampu berpartisipasi aktif dalam kehidupan yang begitu cepat berubah.

Penerapan model Cooperative Learning (CL) terhadap pembelajaran Pendidikan Agama Islam (PAI) dalam Pembentukan Perilaku Belajar Siswa Madrasah Tsanawiyah (MTs) Al Ikhlas Mowewe.

Penerapan model Cooperative Learning $(C L)$ terhadap pembelajaran Pendidikan Agama Islam (PAI) dalam pembentukan perilaku belajar siswa Madrasah Tsanawiyah (MTs) Al Ikhlas Mowewe dalam penerapannya merujuk pada pembelajaran model Cooperative Learning $(C L)$ yang dilakukan secara bersama-sama, saling membantu antara satu dengan yang lain, dan memastikan bahwa setiap orang atau siswa dalam kelompok mampu mencapai tujuan dan menyelesaikan tugas yang diberikan oleh guru. Pembelajaran Pendidikan Agama Islam (PAI) di Madrasah Tsanawiyah (MTs) Al Ikhlas

\footnotetext{
${ }^{11}$ Anita Lie, Mempraktekkan: Cooperative Learning (CL) di Ruang Ruang Kelas, (Jakarta: Gramedia, 2006), h. 31.

${ }^{12}$ Yurnetti, 2008, “Pembelajaran Kooperatif Sebagai Model Alternatif”, Jurnal Himpunan Fisika Indonesia, (online), Vol.B5 (5):h.1.http://hfi.fisika.net/kooperatif/pdf, di akses, 10 Mei 2018.
} 
Mowewe melalui penerapan model Cooperative Learning $(C L)$, dimana siswa dilatih untuk mampu bekerjasama secara bersinergi, integral, dan kombinatif. Selain itu, siswa diajar dan dididik menghindari sifat egois, individualis dan persaingan yang tidak sehat sedini mungkin agar siswa tidak mementingkan pribadi dan kelompoknya saja, sehingga siswa memiliki perilaku belajar yang baik dan positif dan dirasakan manfaatnya.

Penerapan model Cooperative Learning $(C L)$ terhadap pembelajaran Pendidikan Agama Islam (PAI) dalam pembentukan perilaku belajar siswa di Madrasah Tsanawiyah (MTs) Al Ikhlas Mowewe dilaksanakan melalui enam langkah-langkah dalam penerapannya, yaitu: menyampaikan tujuan pembelajaran, menyajikan atau menyampaikan informasi pelaksanaan pembelajaran kelompok, mengorganisasikan siswa dalam kelompok kerjasama dan keanggotaan siswa bersifat heterogen, membimbing, mengarahkan, dan memfasilitasi setiap kelompok, mengevaluasi hasil pembelajaran kelompok, memberikan apresiasi dan penghargaan (reward). ${ }^{13}$

1. Learning Together (belajar kelompok)

Model Cooperative Learning (CL) tipe belajar kelompok (learning together) terhadap pembelajaran Pendidikan Agama Islam (PAI) dalam pembentukan perilaku belajar siswa Madrasah Tsanawiyah (MTs) Al Ikhlas Mowewe dalam penerapannya dalam pembelajaran, dilakukan oleh beberapa orang siswa dengan variasi kemampuan yang berbeda saling belajar, saling berbagi pendapat dan saling membantu dengan kewajiban setiap anggota kelompok benar-benar memahami jawaban dari materi yang ditugaskan sebagai bentuk penyelesaian tugas yang diberikan oleh guru pada kelompok.

Dalam penerapan model Cooperative Learning $(C L)$ tipe belajar kelompok (learning together) terhadap pembelajaran Pendidikan Agama Islam (PAI) dalam pembentukan perilaku belajar siswa Madrasah Tsanawiyah (MTs) Al Ikhlas Mowewe dalam pelaksanaan pembelajaran terdapat, yakni: saling ketergantungan secara positif, interaksi diantara anggota, partisipasi aktif anggota kelompok sangatlah dianjurkankan, selain itu dengan keterampilan pribadi siswa dapat mengembangkannya dalam kelompok. Dari pemaknaan ini dapat dikatakan bahwa pembelajaran melalui tipe belajar kelompok (learning together) merupakan pembelajaran dengan cara siswa disatukan dalam kelompok-kelompok kecil dibawa bimbingan dan pengawasan guru untuk mencapai tujuan pembelajaran melalui kerja sama dan gotong royong atas tugas ataupun materi yang diberikan.

\footnotetext{
${ }^{13}$ Dokumen Sekolah pada tanggal 20 Maret 2018.
} 
Penerapan model Cooperative Learning $(C L)$ terhadap pembelajaran Pendidikan Agama Islam (PAI) tipe belajar kelompok (learning together) dalam pembentukan perilaku belajar siswa Madrasah Tsanawiyah (MTs) Al Ikhlas Mowewe dilaksanakan cukup baik dengan mengikuti langkah-langkah utama pembelajaran model Cooperative Learning $(C L)$, meskipun beberapa kesempatan pembelajaran terdapat guru tidak sempat memberi kesimpulan dan mengevaluasi hasil pembelajaran karena terbatasnya waktu yang disediakan pada setiap mata pelajaran. Penerapan model Cooperative Learning $(C L)$ tipe belajar kelompok (learning together) terhadap pembelajaran Pendidikan Agama Islam (PAI) dalam pembentukan perilaku belajar siswa Madrasah Tsanawiyah (MTs) Al Ikhlas Mowewe menyebabkan terbentuknya beberapa perilaku belajar siswa, diantaranya: kerja sama, terampil, disiplin, berpikir rasional dan kritis, kebiasaan, keterampilan, pengamatan, sikap, Inhibisi, apresiasi dan tingkah laku afektif. ${ }^{14}$

Perilaku belajar siswa terhadap pembelajaran Pendidikan Agama Islam (PAI) pada penerapan model Cooperative Learning $(C L)$ tipe belajar kelompok (learning together) dipandang cukup baik yang ditandai munculnya perilaku belajar siswa, diantaranya: disiplin, terampil, kreatif, inovatif, kebiasaan, sikap, Inhibisi, pengamatan dan tingkah laku afektif. Khusus pada mata pelajaran Bahasa Arab dihadapkan pada hambatan yakni kurangnya perbendaharaan kata (kosa kata) dari siswa sehingga penyelesaian tugas kelompok mengalami keterlambatan. Belajar dengan cara berkelompok pada mata pelajaran Pendidikan Agama Islam (PAI) membuat siswa menyadari akan pentingnya kerja sama kelompok dilakukan secara tepat mengingat waktu pembelajaran yang terbatas. Menjadi catatan, bahwa penilaian yang diutamakan berada pada kelompok dibanding penilaian individu siswa. Atas dasar inilah, membuat siswa semangat mengikuti setiap pembelajaran kelompok.

Bahwa penerapan model Cooperative Learning $(C L)$ menggunakan tipe belajar kelompok (learning together) terhadap pembelajaran Pendidikan Agama Islam (PAI) dalam pembentukan perilaku belajar siswa Madrasah Tsanawiyah (MTs) Al Ikhlas Mowewe telah dilaksanakan cukup baik oleh karena telah menampakkan beberapa bentuk perilaku belajar siswa yang positif seperti: disiplin, kreatif, kebiasaan, Inhibisi, berpikir asosiatif dan daya ingat, dan tingkah laku afektif. Kendala dan hambatan dalam penerapan model Cooperative Learning $(C L)$ pada tipe belajar kelompok (learning together) dalam pembentukan perilaku belajar siswa di Madrasah Tsanawiyah (MTs) Al Ikhlas Mowewe

\footnotetext{
${ }^{14}$ Observasi proses pembelajaran pada tanggal 26 Februari 2018.
} 
dapat diminimalisir dan menjadi bahan evaluasi dan perbaikan pada pembelajaran selanjutnya sehingga pembelajaran PAI melalui tipe belajar kelompok (learning together) mampu membentuk perilaku belajar siswa yang lebih baik sesuai dengan tujuan pembelajaran.

2. Group Discussion (Diskusi Kelompok)

Diskusi kelompok (group discussion) adalah salah satu model Cooperative Learning $(C L)$ digunakan dalam pembelajaran Pendidikan Agama Islam (PAI) di Madrasah Tsanawiyah (MTs) Al Ikhlas Mowewe. Penerapan model Cooperative Learning $(C L)$ terhadap pembelajaran Pendidikan Agama Islam (PAI) dalam pembentukan perilaku belajar siswa pada Madrasah Tsanawiyah (MTs) Al Ikhlas Mowewe melalui tipe diskusi kelompok (group discussion) dimana siswa dapat memecahkan suatu permasalahan yang diberikan dengan tujuan untuk mendapatkan pemahaman bersama secara jelas dan teliti, untuk mengambil keputusan secara bersama sama.

Penerapan model Cooperative Learning $(C L)$ tipe diskusi kelompok (group discussion) terhadap pembelajaran Pendidikan Agama Islam (PAI) dalam pembentukan perilaku belajar siswa Madrasah Tsanawiyah (MTs) Al Ikhlas Mowewe merupakan teknik dalam mempelajari bahan pembelajaran atau materi Pendidikan Agama Islam (PAI) dilakukan oleh siswa secara bersama-sama, bermusyawarah, melalui diskusi kelompok. Penerapan model Cooperative Learning $(C L)$ tipe diskusi kelompok (group discussion) pada pembelajaran Pendidikan Agama Islam terutama pada mata pelajaran Bahasa Arab cukup baik. Hubungan interaksi dan kerja sama diantara siswa telah nampak dimana setiap kelompok terlihat cukup aktif dan kreatif mengerjakan tugas yang diberikan, namun pula masih terdapat beberapa siswa menampakkan ketidakseriusannya oleh karena pemahaman yang kurang terhadap materi. Kendala yang lain yang dihadapi adalah terbatasnya waktu pembelajaran, meskipun dapat diminimalisir dengan mendampingi dan memfasilitasi kesulitan siswa.

Belajar bersama melalui diskusi kelompok memberi manfaat diantaranya: kebiasaan disiplin, berpikir kritis, terampil berkomunikasi, tidak meremehkan teman, saling menghargai perbedaan, kebersamaan dan gotong royong. Pembiasaan disiplin dalam belajar maupun di luar jam belajar di Madrasah Tsanawiyah (MTs) Al Ikhlas Mowewe sangat dianjurkan, misalnya: kedisiplinan waktu belajar, jam istirahat termasuk pelaksanaan shalat dhuhur berjamaah dilakukan tepat waktu dalam rangka menanamkan 
kedisiplinan dan kebersamaan siswa. Membiasakan disiplin dalam shalat berjamaah, oleh siswa memberlakukan absen yang dikoordinir langsung ketua kelas setelah selesai shalat atau sebelum apel siang. Penegakan disiplin dan melalui gerakan pembiasaan pada siswa dan warga sekolah di Madrasah Tsanawiyah (MTs) Al Ikhlas Mowewe diantaranya dibangun melalui proses pembelajaran maupun di luar proses pembelajaran dengan tujuan agar siswa membiasakan disiplin yang dimanifestasikan dalam perilaku belajar siswa yang baik dan Islami di lingkungan sekolah maupun di masyarakat. ${ }^{15}$

Penerapan model Cooperative Learning $(C L)$ tipe diskusi kelompok (group discussion) terhadap pembelajaran Pendidikan Agama Islam (PAI) dalam pembentukan perilaku belajar siswa Madrasah Tsanawiyah (MTs) Al Ikhlas Mowewe cukup baik dan mampu membentuk perilaku belajar siswa, diantaranya: terampil, disiplin, berpikir asosiatif dan daya ingat, berpikir rasional dan kritis, inhibisi, apresiasi, dan tingkah laku afektif. Namun masih terdapat diantara siswa bentuk perilaku belajarnya belum sesuai keinginan melalui penerapan model Cooperative Learning $(C L)$ tipe diskusi kelompok (group discussion), seperti ; kurang disiplin, kurang kerjasama, kurang menghargai pendapat dan kurang memberi respon dalam pembelajaran dan kurang percaya diri mengemukakan ide dan pendapat pada diskusi kelompok. Hambatan yang masih dirasakan dalam penerapan model Cooperative Learning $(C L)$ tipe Diskusi Kelompok (group discussion) terhadap pembelajaran Pendidikan Agama Islam (PAI) dalam pembentukan perilaku belajar siswa di Madrasah Tsanawiyah (MTs) Al Ikhlas Mowewe menjadi bahan evaluasi dan perbaikan pada pembelajaran berikutnya.

3. Jigsaw

Pembelajaran Pendidikan Agama Islam (PAI) menggunakan model Cooperative Learning (CL) tipe Jigsaw dalam pembentukan perilaku belajar siswa di Madrasah Tsanawiyah (MTs) Al Ikhlas Mowewe diawali dengan pengenalan topik yang akan dibahas dalam pembelajaran oleh guru. Pada teknik ini, guru menuliskan topik yang akan dibahas atau dipelajari selanjutnya, guru menanyakan pada siswa tentang apa saja yang mereka ketahui mengenai topik atau pada materi yang akan dibahas. Kegiatan sumbang saran ini mempunyai tujuan mengaktifkan struktur kognitif siswa agar lebih siap dalam pembelajaran yang akan dilaksanakan. Setiap siswa dalam kelompok ahli diberi tugas untuk mempelajari materi tertentu. Kemudian, perwakilan dari masing-masing kelompok bertemu dan mempelajari materi yang sama. Selanjutnya, materi didiskusikan sehingga

\footnotetext{
${ }^{15}$ Dokumen Sekolah pada tanggal 7 Maret 2018.
} 
perwakilan kelompok dapat memahami dan menguasai dengan baik materi yang telah dibahas tersebut. Penerapan model Cooperative Learning $(C L)$ tipe Jigsaw terhadap pembelajaran Pendidikan Agama Islam (PAI) dalam pembentukan perilaku belajar siswa membutuhkan proses yang sistematis dan berkesinambungan.

Penerapan model Cooperative Learning $(C L)$ terhadap pembelajaran Pendidikan Agama Islam (PAI) tipe Jigsaw dalam pembentukan perilaku belajar siswa Madrasah Tsanawiyah (MTs) Al Ikhlas Mowewe keterlibatan guru berkurang karena perannya sebagai fasilitator dengan mengarahkan dan memotivasi siswa untuk belajar mandiri serta menumbuhkan rasa tanggungjawab pada diri mereka. Meskipun demikian, guru tetap mengendalikan, walaupun tidak menjadi pusat perhatian utama dalam pelaksanaan pembelajaran kelompok. ${ }^{16}$ Teknik dalam pembelajaran tipe Jigsaw menjadi solusi alternatif yang cukup menarik pada materi belajar yang bisa disegmentasikan. Tiap siswa mempelajari setiap bagian dari materi yang bila digabungkan akan membentuk pengetahuan yang utuh dan terpadu. Model Cooperative Learning $(C L)$ tipe Jigsaw dapat digunakan ketika guru menyampaikan materi pembelajaran, dimana materi-materi disegmentasikan yang selanjutnya dipelajari masing-masing siswa dalam kelompok.

Penerapan model Cooperative Learning $(C L)$ tipe Jigsaw terhadap pembelajaran Pendidikan Agama Islam (PAI) dalam pembentukan perilaku belajar siswa di Madrasah Tsanawiyah Al Ikhlas Mowewe dalam pengamatan di lapangan tepat dan cocok diterapkan pada semua tingkatan atau kelas. Dalam teknik ini, guru dapat mengetahui, memperhatikan latar belakang pengalaman siswa dan membantu siswa untuk lebih aktif dalam kelompok sehingga bahan pelajaran dapat dikuasai dan menjadi lebih bermakna pada siswa. Penerapan model Cooperative Learning (CL) tipe Jigsaw terhadap pembelajaran Pendidikan Agama Islam (PAI) dalam pembentukan perilaku belajar siswa di Madrasah Tsanawiyah (MTs) Al Ikhlas Mowewe diharapkan mampu membangkitkan motivasi, inspirasi dan kreativitas para siswa untuk belajar mandiri, menumbuhkan rasa solidaritas, kerja sama, dan tanggungjawab dalam kelompok ahlinya masing-masing. ${ }^{17}$

Menerapkan model Cooperative Learning $(C L)$ tipe Jigsaw terhadap pembelajaran Pendidikan Agama Islam (PAI) dalam pembentukan perilaku belajar siswa Madrasah Tsanawiyah (MTs) Al Ikhlas Mowewe, meskipun guru tidak menjadi pusat perhatian dalam pembelajaran yang sedang berlangsung melainkan berada pada siswa

${ }^{16}$ Observasi pada tanggal 6 Februari 2018. 
namun guru tetap memantau, memfasilitasi dan mengendalikan jika terjadi kesulitan dan hal yang memerlukan penjelasan seperti terdapat materi yang belum dipahami oleh kelompok. Penerapan model Cooperative Learning $(C L)$ terhadap pembelajaran Pendidikan Agama Islam (PAI) melalui tipe Jigsaw melahirkan beberapa bentuk perilaku belajar siswa seperti : kebiasaan, keterampilan, berpikir rasional dan kritis, apresiasi, Inhibisi, berpikir asosiatif dan daya ingat, serta perilaku afektif. Disamping itu nampak pula perilaku positif siswa dengan kemampuan bekerja sama dengan teman-temannya dalam suasana gotong royong sehingga mereka mempunyai banyak kesempatan mengola informasi dan meningkatkan keterampilan berkomunikasi.

Belajar dengan cara membentuk tim ahli (Jigsaw) dalam satu kelompok pada mata pelajaran Pendidikan Agama Islam (PAI) menyebabkan siswa lebih disiplin, serius, dan semangat. Intinya belajar kelompok melalui tim ahli (Jigsaw) memberi manfaat positif. Kendala yang dirasakan selama ini adalah waktu pembelajaran yang terbatas, sehingga tidak cukup waktu untuk menjelaskan materi dengan baik dan tuntas pada kelompok asal karena tersita waktu pada pembahasan di tim ahli. Penerapan model Cooperative Learning $(C L)$ tipe Jigsaw terhadap pembelajaran Pendidikan Agama Islam (PAI) dalam pembentukan perilaku belajar siswa pada Madrasah Tsanawiyah (MTs) Al Ikhlas Mowewe cukup baik, meskipun dalam pelaksanaannya terdapat beberapa siswa yang masih menemukan kesulitan diantaranya kurang menguasai materi sehingga pada laporan hasil kerja tim ahli setelah kembali ke kelompok awalnya menjadi tidak maksimal. ${ }^{18}$

Bahwa belum dikuasainya materi secara tuntas oleh beberapa siswa disebabkan karena keterbatasan bahan ajar/buku dan dari tim ahli dalam pelaksanaan pembelajaran dan kurang optimalnya guru memfasilitasi kesulitan siswa. Hambatan lain dalam pelaksanaan pembelajaran Pendidikan Agama Islam (PAI) melalui penerapan model Cooperative Learning (CL) tipe Jigsaw pada Madrasah Tsanawiyah (MTs) Al Ikhlas Mowewe bersumber pada guru karena pada awal pembelajaran kurang memberi penjelasan dengan baik dan tuntas tentang teknik pembelajaran tipe Jigsaw termasuk kejelasan materi sehingga terdapat tim ahli terlambat menyelesaikan tugas. Guru seharusnya tetap mengawasi, membantu dan memfasilitasi kesulitan siswa sehingga tujuan yang diinginkan dapat tercapai.

\footnotetext{
${ }^{18}$ Dokumen Sekolah pada tanggal 6 Februari 2018.
} 


\section{Penutup}

Penerapan model Cooperative Learning $(C L)$ terhadap pembelajaran Pendidikan Agama Islam (PAI) dalam pembentukan perilaku belajar siswa Madrasah Tsanawiyah (MTs) Al Ikhlas Mowewe melalui tiga tipe, yakni: tipe belajar kelompok (learning together), diskusi kelompok (group discussion) dan tipe Jigsaw. Penelitian ini menunjukkan bahwa penerapannya dilaksanakan cukup baik dengan mengikuti langkahlangkah pembelajaran model Cooperative Learning $(C L)$ yang disesuaikan dengan materi atau bahan pembelajaran dalam rangka pembentukan perilaku belajar siswa. Penelitian ini diharapkan memberi kontribusi positif dan senantiasa mendorong sikap proaktif mengembangkan pembelajaran model Cooperative Learning $(C L)$. Dengan demikian, pembelajaran model Cooperative Learning $(C L)$ yang dilaksanakan saat ini dan yang akan datang menjadi aktual, relevan, efektif dan responsif terhadap dinamika zaman.

\section{DAFTAR PUSTAKA}

Badiatul Hikmah. Pembelajaran Kooperatif (Studi dalam pembelajaran Fiqh tipe Jigsaw MTs. Sunan Giri Prigen Gutter, Pasuruan) Journal Islam Education, (online)Vol.2.No.1 http://ejournal.Stimuhbangil.ac.id/Index.php/article/view/44 diakses tanggal 11 Mei 2018.

Fisman.2017.com,makalah-psikologi-belajar-manifestasi-perilaku-belajar.php, (online),http:www.Kosmaext,2017.com. diakses tanggal 11 Mei 2018.

Lie, Anita. Cooperative Learning: Mempraktekkan Cooperative Learning Di RuangRuang Kelas. Jakarta: Gramedia. 2005.

Silbermen, L. Melvin, “Active Learning” 101 Strategi Pembelajaran Aktif. Jogjakarta: Pustaka Insan Madani. 2007.

Sanjaya Wina, Strategi Pembelajaran Standar Proses. Jakarta: Kencana Prenada Media Group, 2012.

Supriyono, Psikologi Belajar. Jakarta: PT. Rineka Cipta. 2011.

R.E, Slavin. Research on Cooperative Learning and: What we need to know Contemporary Educational Psychology. (Terjemah Yusron Nurlita), Bandung: Nusa Media. 2008.

Rusman, "Model-Model Pembelajaran, Mengembangkan Profesionalisme Guru". Jakarta: Rajawali Press. 2011.

Yurnetti, "Pembelajaran Kooperatif sebagai Model Alternatif”, Jurnal Himpunan Fisika Indonesia, (online), Vol. B5 (5):h.1.http://hfi.fisika.net/kooperatif/pdf, diakses 10 Mei 2018. 